\title{
New approaches toward anti-Rhipicephalus (Boophilus) microplus tick vaccine
}

\author{
Novas estratégias para o desenvolvimento de uma vacina \\ contra o carrapato Rhipicephalus (Boophilus) microplus
}

Luís Fernando Parizi ${ }^{1}$; Paula Cristiane Pohl' ${ }^{1}$; Aoi Masuda ${ }^{1,2}$; Itabajara da Silva Vaz Junior ${ }^{1,3 *}$

${ }^{1}$ Centro de Biotecnologia, Universidade Federal do Rio Grande do Sul - UFRGS

${ }^{2}$ Departamento de Biologia Molecular e Biotecnologia, Universidade Federal do Rio Grande do Sul - UFRGS

${ }^{3}$ Faculdade de Veterinária, Universidade Federal do Rio Grande do Sul - UFRGS

Received December 1, 2008

Accepted January 30, 2009

\begin{abstract}
The tick Rhipicephalus (Boophilus) microplus (formerly Boophilus microplus) is the major ectoparasite affecting livestock in America, Asia, Africa, and Oceania. Conventional tick control is based on the use of acaricides but immunization of bovines with tick gut proteins induces only a partial protective immune response. Based on this information, distinct research groups have explored the possibility of protecting the animals by inducing an immune response against other tick proteins. However, the antigens so far described do not induce the necessary protection for suppressing the use of acaricides. Currently, several groups are engaged in identifying new tick proteins to be used as targets for the development of new vaccines. This approach focuses on the enhancement of the immunogenicity of antigens already tested by incorporating new adjuvants or formulations and by searching for new antigens. This paper reviews the work done by Brazilian researchers to develop a vaccine against this tick.
\end{abstract}

Keywords: Boophilus microplus, Rhipicephalus microplus, vaccine, tick, control.

\section{Resumo}

O carrapato Rhipicephalus (Boophilus) microplus (anteriormente Boophilus microplus) é o principal ectoparasita que afeta bovinos na América, Ásia, África e Oceania e o seu controle é tradicionalmente realizado através do uso de acaricidas. Experimentos de imunização com proteínas do carrapato mostram que a resposta imune desenvolvida pelos bovinos vacinados protege, em parte, os animais do parasitismo. Baseado nessas observaçôes, vários grupos de pesquisa exploram a possibilidade de proteger os animais pela induçáo de uma resposta imune contra proteínas do carrapato. Entretanto, os antígenos já caracterizados não asseguram o grau de proteçáo necessário para suprimir o uso de acaricidas. Portanto, esses grupos de pesquisa estão engajados na tentativa de identificar novas proteínas que possam ser utilizadas para o desenvolvimento de novas vacinas, as quais possam induzir maior imunogenicidade de que os antígenos já testados, através do uso de novas formulaçóes e/ou pela incorporaçáo de adjuvantes. O presente artigo apresenta uma revisão da literatura sobre os resultados obtidos por pesquisadores brasileiros no desenvolvimento de vacinas contra o carrapato.

Palavras-chave: Boophilus microplus, Rhipicephalus microplus, vacina, carrapato, controle.

\section{Introduction}

The tick Rhipicephalus (Boophilus) microplus (formerly Boophilus microplus) (MURRELL et al., 2003) is a blood-sucking parasite that transmits Babesia spp. and Anaplasma spp. to cattle (CAFRUNE et al., 1995). It causes significant economic losses in tropical and subtropical areas of world. The infestation of bovines by ticks is one of the main causes of low productivity of grazing cattle in Brazil. The economic impact caused by tick in-

\footnotetext{
*Corresponding author: Itabajara da Silva Vaz Júnior

Centro de Biotecnologia, Universidade Federal do Rio Grande do Sul - UFRGS Av. Bento Gonçalves 9.500, Prédio 43421, CEP 91501-970 Porto Alegre - RS, Brazil Tel.: +55 (51) 3308-6078, Fax: +55 (51) 3308-7309; e-mail: ita@cbiot.ufrgs.br
}

festations is tens of billions of dollars per year, worldwide. These enormous economic losses could be minimized by the control of tick populations down to acceptable levels. Conventional tick control is based on the use of acaricides (MARTINS et al., 2002). However, the improper use of these molecules has increased the incidence of acaricide-resistant ticks (CRAMPTON et al., 1999; MARTINS et al., 2001; KLAFKE et al., 2006), besides increasing the occurrence of environmental and food contamination. Together, these problems generate a rising economic and social demand for new control methods. 
Non-chemical alternative methods include the use of genetically resistant animals (GASPARIN et al., 2007), the management of pastures, as well as the adoption of both biological (FRAZZON et al., 2000; BENJAMIN et al., 2002; FERNANDES et al., 2004; BASSO et al., 2005; BAHIENSE et al., 2006; LEEMON et al., 2008) and of immunologic control strategies. However, in these alternative methods, knowledge of bovine immunology, for instance the characterization of cutaneous hypersensitivity in tick susceptible/resistant bovines (BECHARA et al., 2000); of the modulation of immune responses by parasite components (KASHINO et al., 2005) or intensity of tick infestation (CRUZ et al., 2008); of the influence of host genotypic composition in the induction of an immune response (CARVALHO et al., 2008), as well as the dynamics of the tick populations (EVANS et al., 2000; MARTINS et al., 2002) that occur in each region, are all equally fundamental factors for the success of control programs. These studies underscore the importance of the characterization of host immune response for the development of new vaccines and are important in accelerating the process of bringing tick vaccines from the development stage to clinical use. Together, biological and immunological controls offer considerable potential for reduction in the use of chemicals in integrated control of ectoparasites.

Vaccines have been used in some countries, although without solving the problem completely. In this scenario, the use of acaricides is still necessary (PRUETT, 1999). Nevertheless, vaccines undoubtedly are suitable targets for research efforts aimed at the control of the parasite. Hence, knowledge of the biology of the parasite as well as of the interaction of the tick with the vertebrate are basic instruments for the formulation and application of this control method.

We carried out a literature review to characterize the production of Brazilian research groups in the development of a vaccine against $R$. (B.) microplus. The survey of scientific production in the period from 2001 to 2008 related to this tick reveals that efforts of Brazilian researchers represent approximately one fifth of the world's scientific output dedicated to the study of the bovine tick (indexed articles in ISI, using Boophilus as the key word).

\section{Immune Response Against the Tick}

The idea of controlling tick parasitism through immunological means has been studied for more than 40 years (ROBERTS, 1968; WAGLAND et al., 1985). These studies make clear that the existence of natural resistance to ticks in bovines is not only of innate origin, it is also acquired during successive infestations (ALLEN, 1994; BARRIGA et al., 1995) and resistant animals can reject 80 to $99 \%$ of the larvae (ALLEN, 1994). These observations are the basis for all the studies aiming at tick control by means of vaccines. Among the advantages of vaccines is the increased safety for the applicator as well as for the consumer, due to the fact that it is not necessary to observe a lag period after vaccine application, unlike the application of chemical products.

Mechanisms of parasite evasion from the immunological response already identified in different species of ticks include immunosuppressor factors, inhibitors of the complement sys- tem, T cell cytotoxicity, inflammatory response, and interleukins (BARRIGA, 1999). Efficiency in preventing the hosts' protection mechanisms has gradually evolved throughout the long period of co-evolution of the parasite and its hosts. The host-immune response and the evasion mechanisms (BARRIGA, 1999; MULENGA et al., 2002) of the parasite are in an extremely fine balance that allows the survival of both species. Due to the lack of contact between the concealed antigens and the immune system of the bovine, the ticks have not had the chance to develop strategies to escape from the immune response against concealed antigens (WILLADSEN et al., 1988), therefore the immune response against this type of antigen would be, theoretically, more efficient than a natural immune response (WILLADSEN et al., 1988).

\section{Anti-Tick Vaccines Currently Available}

In development of an anti-tick vaccine, two sources of candidate vaccine antigens have been characterized: (a) the "exposed" antigens, that is, those present in tick saliva and inoculated in the bovine during the feeding process; and (b) "concealed" antigens, which are normally hidden from the bovine immune response (WILLADSEN et al., 1988). At the moment, there are two commercially available vaccines (in Australia and in Cuba) that partially control $R$. (B.) microplus. Both vaccines are based on the $\mathrm{Bm} 86$ protein. This protein was obtained, initially, through the purification of the protein by fractioning the whole tick using chromatographic methods (WILLADSEN et al., 1988). The $\mathrm{Bm} 86$ is a glycoprotein present in the membrane of gut cells and it plays a role in endocytosis (WILLADSEN et al., 1989). The effectiveness of the available vaccines that use a recombinant Bm 86 protein produced in bacteria or yeast varies between 51 and $91 \%$, according to the characteristics of each tick population and to the nutritional condition of the bovines used in the tests (KEMP et al., 1989; PENICHET et al., 1994; RODRIGUEZ et al., 1995; PATARROYO et al., 2002). It was suggested that the variation in effectiveness observed between different regions of the world is due to variations in the sequence of the $\mathrm{Bm} 86$ between different tick populations (GARCIA-GARCIA et al., 2000). Indeed, analyses of tick populations from Argentina have shown polymorphisms in the gene of $\mathrm{Bm} 86$ that resulted in a soluble protein instead the membrane-bound protein detected in ticks from Australia and Cuba, which explains why Argentinean ticks are resistant to vaccination. To overcome this resistance, a new recombinant vaccine was produced based on the gene of Bm95 (allele of the Bm86 gene). This new antigen was efficient to protect bovines from infestations by ticks from Argentina and Cuba (GARCIA-GARCIA et al., 2000).

Another strategy employed to induce an immune response against $\mathrm{Bm} 86$ was the use of DNA vaccines containing the Bm86 gene. Sheep, mice, and bovines immunized with plasmids encoding for the $\mathrm{Bm} 86$ gene produced a humoral immune response, with production of immunoglobulins, especially IgG-class antibodies, for Bm86 antigen (DE ROSE et al., 1999; RUIZ et al., 2007). After vaccination, the sheep showed a partial protection against subsequent tick infestation (DE ROSE et al., 1999). 
Additionally, bovines vaccinated with $\mathrm{Bm} 86$ showed variable levels of resistance against $R$. (B.) microplus (ANDREOTTI, 2006) and against closely related species challenges (FRAGOSO et al., 1998; DE VOS et al., 2001; ODONGO et al., 2007). These protection levels reflect the variation between $R$. (B.) microplus isolates, and also point to the phylogenetic relationships between tick species, indicating that immunologically important epitopes are partially conserved (SOSSAI et al., 2005; ODONGO et al., 2007; ANDREOTTI et al., 2008).

Through the analysis of Bm86 and the evaluation of some properties of this protein, such as its hydrophobic and hydrophilic potentials, synthetic peptides derived from this glycoprotein sequence have been developed. When used as vaccinal antigens in bovines, these peptides presented effectiveness between 36 and 81\% (PATARROYO et al., 2002). One of these synthetic peptides ( $\mathrm{SBm} 7462)$ was used in an encapsulated form in polyester microspheres, and also emulsified in saponin. It was demonstrated that saponin was effective in inducing $\operatorname{IgG}$ antibodies (SALES-JUNIOR et al., 2005). As the amino acid sequence variability of SBm7462 epitope may affect the performance of immunization against ticks, the $\mathrm{Bm} 86$ gene coding region of SBm7462-epitope was sequenced from 20 tick isolates. The analyses indicated that the SBm7462 gene is conserved in South American tick populations. The SBm7462 conservation reported supports the use of this peptide as antigen in a vaccine against different tick populations (PECONICK et al., 2008).

\section{Potential Candidates for New Vaccines}

Knowledge of tick physiology and of bovine immunology are also limited. So, in order to provide conditions to support the development of new control strategies, the researcher is faced with the primary need to understand host-parasite interaction. Challenges associated with this objective include the understanding of tick physiology and bovine immunology. Various research groups are engaged in trying to identify new tick proteins as targets for the development of new vaccines, and also devote their efforts to the enhancement of immunogenicity of antigens already tested, by incorporating new adjuvants or formulations into the original research (IMAMURA et al., 2007).

\section{Hemelipoproteins}

The protection mechanisms against oxidative damage caused by the ingestion of great amounts of blood and the mechanisms to oppose the hemostatic defenses of the host are major elements of an attractive strategy directed to discover new molecules as potential candidates for the development of an effective vaccine.

Hemoglobin digestion in the tick's gut is intracellular (AKOV, 1982) and a cisteine-protease seems to be related to hemoglobin digestion (RENARD et al., 2002). It occurs exclusively inside large vesicles of the digestive cell of the intestinal tract (LARA et al., 2005), resulting in the production of high amounts of heme inside the cell. By testing the hypothesis of the existence of adaptations by the tick to the toxicity of heme, it was possible to show that the first defense of the intestine consists in sequestering around $90 \%$ of the heme from the blood meal into an organelle dedicated to this function: the hemosome (LARA et al., 2003). It has been shown that the $R$. (B.) microplus does not synthesize heme, using part of the heme ingested in the diet (the remaining $10 \%$ ) to mount its own hemeproteins (BRAZ et al., 1999). Moreover, $R$. (B.) microplus is the only animal proven to not synthesize heme. Clearly, this demonstrates that this parasite is unique in many aspects, and inferences based on the knowledge of other species cannot be made easily. The heme absorbed in the midgut is transferred to hemolymph and transported by a hemelipoprotein - HeLp to the tissues (MAYA-MONTEIRO et al., 2000). It has been shown that the lipoproteic particle of this protein plays an antioxidant role against heme-induced radical damage (MAYA-MONTEIRO et al., 2004). Additionally, the HeLp protein can be also implicated in the transport of lipids.

It has also been shown that hemoglobin digestion in the digestive tract produces antimicrobial peptides (FOGACA et al., 1999), revealing an association between the immune system and the digestive system. Other antimicrobial peptides present in tick hemolymph have been identified and suggested to play an essential role for survival and prevention of pathogen invasion throughout the tick's body (FOGACA et al., 2004, 2005).

\section{Tick heme-binding aspartic proteinase - THAP}

In the adult female tick, the main use of blood meal is the maintenance of the reproductive effort, represented by a massive production of eggs. Yolk accumulation (vitellogenesis) is a process in which extraovarian tissues produce proteins precursors that are transported to and accumulated inside the oocytes (GIORGI et al., 1985; RAIKHEL et al., 1992) in order that eggs, together with the genetic material, have all the substrates needed for a complete development of the new living being.

The study of egg protein constituents, the sites in which they are produced, the way they gather inside the oocyte, as well as the pathway through which they are mobilized during embryogenesis are aspects of a general strategy that will allow, in the long run, collection of information on the tick reproductive process and that will be helpful in finding new targets for vaccines or for drugs. In this sense, understanding of the steps involved in egg production and development, the characterization of the egg's fragilities, will equally be essential in developing alternative strategies for tick population control.

Another way to influence the reproductive process lies in controlling yolk consumption. Enzymes such as phosphatases, kinases, and proteases, generally acidic and of maternal origin, are accumulated in the oocytes during vitellogenesis (OLIVEIRA et al., 1989; RIBOLLA et al., 1993; FIALHO et al., 2005). They are responsible for yolk degradation (POHL et al., 2008) and are activated by acidification after the fertilization event (FAGOTTO, 1995). This entire enzyme repertory could be useful in finding new targets to develop an effective vaccine.

The embryo of $R$. (B.) microplus is of the long germinal band type (occupies the entire egg in the blastoderm stage), similarly to what is observed in diptera, although the morphogenetic movements are distinct in this group (CAMPOS et al., 2006). The 
tick energetic metabolism has been investigated in the different embryogenesis phases. An interesting observation is that all proteases already characterized are proteinases that require an acidic $\mathrm{pH}$ to become activated (LOGULLO et al., 1998; SEIXAS et al., 2003; POHL et al., 2008). Indeed, it has been observed that eggs of $R$. (B.) microplus possess a proton ATPase of the vacuolar type, which is involved in the process of acidification and which would probably lead to the activation of these proteolytic enzymes in specific compartments (ABREU et al., 2004). Moreover, the presence of trypsin inhibitors (ANDREOTTI et al., 2002; AZZOLINI et al., 2003; SASAKI et al., 2004) and inhibitors of cysteine proteases (LIMA et al., 2006) suggests that these inhibitors play a role in the control of embryo metabolism.

The observation that eggs accumulate a great amount of heme after vitellin - VT processing/degradation (vitellin is the main protein of reserve of eggs) (LOGULLO et al., 2002) supports the hypothesis that the degradation of vitellin during the embryonic development is a source of oxidative stress. Therefore, a critical adaptation is necessary, which may prevent excessive reactive oxygen species production during several physiologic conditions. This finding supports the hypothesis that an egg VT degradation aspartic protease called Tick Heme-binding Aspartic Proteinase - THAP present in eggs has its activity inhibited by heme through a site that is distinct from the catalytic site (SORGINE et al., 2000; POHL et al., 2008). The increase in egg free heme content would generate a feedback inhibition in VT degradation. The idea that VT degradation is a process related to the regulation of redox balance and to the use of heme by the embryo was reinforced by the demonstration that VT is also a heme binding protein and that it inhibits lipid peroxidation induced by heme (LOGULLO et al., 2002).

\section{Boophilus yolk pro-cathepsin and tick vitellin-degrading enzyme}

The Boophilus Yolk pro-Cathepsin - BYC seems to be associated with the mobilization of VT (LOGULLO et al., 1998). Also, the identification of a cysteine protease strongly associated with VT suggests the possibility that this protein is also involved in the degradation of VT, and characterizes the use of yolk as being a highly regulated process, involving a joint action of different enzymes (SEIXAS et al., 2003).

It was observed that total egg protein remains stable during embryogenesis (CAMPOS et al., 2006), while VT content suffers a variation (CANAL et al., 1995; LOGULLO et al., 2002). Thus, VT is used for the supply of the amino acids required to synthesize new proteins. In addition, at the end of embryogenesis the glucose is obtained from the amino acid catabolism. Surprisingly, in the eggs this process is accompanied by a significant glycogen re-synthesis (CAMPOS et al., 2006). These data suggest the existence of a rather complex system of control of energy metabolism in the embryogenesis of this tick.

Experiments directed at developing protocols to immunize bovines with proteins have been conducted. This idea is supported by the demonstration that functional antibodies are found in tick hemolymph when ticks take a meal in an immunized bovine
(DA SILVA VAZ Jr. et al., 1996). This finding opened the way to use proteins from other tick organs as targets for vaccines, and not just proteins from the digestive tract. Immunization of bovines with native (DA SILVA VAZ Jr. et al., 1998) or recombinant form (LEAL et al., 2006) of an egg-yolk aspartic endopeptidase - BYC could interfere with the reproductive process of the tick, with reduction in the number of engorged ticks, in egg-laying capacity, and in egg fertility. Immunization of bovines with native BYC induced an overall protection of around 30\% (DA SILVA VAZ Jr. et al., 1998). In comparison, the immunization with the recombinant form of BYC induced an overall protection of around 25\% (LEAL et al., 2006). Since BYC immunization interferes in functions related to the target protein, in this case those related to embryonic and egg development, it is possible to assume that vaccination with other embryo proteins can be efficient to intervene in tick embryonic and larval phases. Recently, it has been shown that immunization of bovines with a cysteine endopeptidase - VTDCE, an enzyme also involved in the digestion of vitellin (SEIXAS et al., 2003), leads to a certain degree of immunoprotection ( $21 \%$ of overall protection rate) in vaccinated cattle (SEIXAS et al., 2008).

Similarly, significant protection (reduction of $69.7 \%$ in the total tick number) against tick infestations was obtained by immunizing bovines with a set of trypsin inhibitors present in $R$. (B.) microplus larvae. A trypsin inhibitor (BmTI-A) was purified from the set of trypsin inhibitors and then partially sequenced. So, a synthetic peptide based on the BmTI-A was used to immunize bovines. However, the efficacy was only of $18.4 \%$, specifically in the reduction in the number of engorging ticks (ANDREOTTI, 2007). These results suggest that the larval feeding process is affected by the bovine immune response, leading to damage to ticks at the early stages of development (TANAKA et al., 1999; ANDREOTTI et al., 2002).

Other strategies to find novel proteins involved with the parasite-host relationship are large-scale analyses, which have the power to survey the entire genome and identify genes (and proteins) with potential use for vaccine development.

Expressed Sequence Tag - EST libraries have shown to be powerful tools for gene discovery (NAGARAJ et al., 2007). ESTs were generated by large-scale sequencing of clones from cDNA libraries constructed from mRNA isolated from ovaries, hemocytes, and salivary glands of $R$. (B.) microplus and 1,344 were deposited in sequence databases (SANTOS et al, 2006). The potential functions of many proteins were deduced based on their homologies to known proteins. Approximately 30\% of these ESTs represented new proteins in this tick. Knowing these potential new proteins may shed light on the biology, taxonomy and phylogeny of the parasite while it represents a new way of performing biological studies.

One of these meta-analysis methods, namely the phage display technique, is an antibody-based proteomic approach that has great potential in identifying and characterizing antigens to be used in vaccines. The phage display technique permitted to identify, in a high-throughput manner, 66 tick proteins that showed potential for eliciting a host immune response after infestation. Simultaneously, bioinformatics analysis revealed protein features known to be important for antigen selection, which led to the identification of novel and potential vaccine candidates (PRUDENCIO et al., 2009). 


\section{Conclusion}

Various approaches have established that immunizations with tick native or recombinant proteins or with synthetic peptides are useful to induce a partially protective immune response, and that these immunizations could be used together with acaracides for an efficient tick control. This review emphasizes the feasibility of the research work developed in Brazil, which aims to improve innovation in the development of the vaccine against ticks. The increasing Brazilian contribution in this field places our country as an international reference for acarologists. Clearly, the interaction between applied and basic research is characteristic of the Brazilian research work in this field. Indeed, this is indispensable to generate national knowledge and technology in the cattle-breeding sector.

\section{Acknowledgments}

This work was supported by grants from CNPq-Instituto Nacional de Entomologia Molecular, HHMI, FINEP, CAPES, CNPq, FAPERJ, and FAPERGS.

\section{References}

ABREU, L. A. et al. Proteolytic activity of Boophilus microplus Yolk pro-Cathepsin D (BYC) is coincident with cortical acidification during embryogenesis. Insect Biochemistry and Molecular Biology, v. 34, n. 5, p. 443-449, 2004.

AKOV, S. Blood digestion in ticks. In: OBENCHAIN, F.; GALUN, R. (ed.). Physiology of Ticks. Oxford: Pergamon Press, 1982. p. $197-211$.

ALLEN, J. R. Host resistance to ectoparasites. Revue scientifique et technique, v. 13, n. 4, p. 1287-1303, 1994.

ANDREOTTI, R. A synthetic BmTI n-terminal fragment as antigen in bovine immunoprotection against the tick Boophilus microplus in a pen trial. Experimental Parasitology, v. 116, n. 1, p. 66-70, 2007.

ANDREOTTI, R. et al. BmTI antigens induce a bovine protective immune response against Boophilus microplus tick. International Immunopharmacology, v. 2, n. 4, p. 557-563, 2002.

ANDREOTTI, R. et al. Comparison of predicted binders in Rhipicephalus (Boophilus) microplus intestine protein variants Bm86 Campo Grande strain, Bm86 and Bm95 Comparação da previsão de ligação das variantes de proteína de intestino de Rhipicephalus (Boophilus) microplus Bm86 cepa Campo Grande, Bm86 e Bm95. Brazilian Journal of Veterinary Parasitology, v. 17, n. 2, p. 93-98, 2008.

ANDREOTTI, R. Performance of two Bm86 antigen vaccine formulation against tick using crossbreed bovines in stall test. Revista Brasileira de Parasitologia Veterinária, v. 15, n. 3, p. 97-100, 2006.

AZZOLINI, S. S. et al. Rhipicephalus sanguineus trypsin inhibitors present in the tick larvae: isolation, characterization, and partial primary structure determination. Archives of Biochemistry and Biophysics, v. 417, n. 2, p. 176-182, 2003.

BAHIENSE, T. C.; FERNANDES, E. K. K.; BITTENCOURT, V. R. E. P. Compatibility of the fungus Metarhizium anisopliae and deltamethrin to control a resistant strain of Boophilus microplus tick. Veterinary Parasitology, v. 141, n. 3-4, p. 319-324, 2006.

BARRIGA, O. O. Evidence and mechanisms of immunosuppression in tick infestations. Genetic Analysis-Biomolecular Engineering, v. 15, n. 3-5, p. 139-142, 1999.

BARRIGA, O. O.; DA SILVA, S. S.; AZEVEDO, J. S. Relationships and influences between Boophilus microplus characteristics in tick-naive or repeatedly infested cattle. Veterinary Parasitology, v. 56, n. 1-3, p. 225-238, 1995.

BASSO, L. M. D. et al. Control of Boophilus microplus larvae by Metarhizium anisopliae in artificially infested pastures. Pesquisa Agropecuaria Brasileira, v. 40, n. 6, p. 595-600, 2005.

BECHARA, G. H.; MORELLI, J.; SZABO, M. P. J. Skin test and tick immune status in susceptible and resistant cattle in Brazil. Tropical Veterinary Diseases, v. 916, p. 570-575, 2000.

BENJAMIN, M. A.; ZHIOUA, E.; OSTFELD, R. S. Laboratory and field evaluation of the entomopathogenic fungus Metarhizium anisopliae (Deuteromyeetes) for controlling questing adult Ixodes scapularis (Acari: Ixodidae). Journal of Medical Entomology, v. 39, n. 5, p. 723-728, 2002.

BRAZ, G. R. et al. A missing metabolic pathway in the cattle tick Boophilus microplus. Current Biology, v. 9, n. 13, p. 703-706, 1999.

CAFRUNE, M. M. et al. Experimental studies of the rate of infection of Boophilus microplus eggs with Babesia bovis. Research in Veterinary Science, v. 58, n. 3, p. 284-285, 1995.

CAMPOS, E. et al. Kinetics of energy source utilization in Boophilus microplus (Canestrini, 1887) (Acari : Ixodidae) embryonic development. Veterinary Parasitology, v. 138, n. 3-4, p. 349-357, 2006.

CANAL, C. W. et al. Changing patterns of vitellin-related peptides during development of the cattle tick Boophilus microplus. Experimental \& Applied Acarology, v. 19, n. 6, p. 325-336, 1995.

CARVALHO, W. A. et al. Rhipicephalus (Boophilus) microplus: Distinct acute phase proteins vary during infestations according to the genetic composition of the bovine hosts, Bos taurus and Bos indicus. Experimental Parasitology, v. 118, n. 4, p. 587-591, 2008.

CRAMPTON, A. L.; BAXTER, C. D.; BARKER, S. C. A new family of cytochrome P450 genes (CYP41) from the cattle tick, Boophilus microplus. Insect Biochemistry and Molecular Biology, v. 29, n. 9, p. 829-834, 1999.

CRUZ, A. P. et al. Comparative IgG recognition of tick extracts by sera of experimentally infested bovines. Veterinary Parasitology, v. 158, n. 1-2, p. 152-158, 2008.

DA SILVA VAZ Jr., I. et al. Immunization of bovines with an aspartic proteinase precursor isolated from Boophilus microplus eggs. Veterinary Immunology and Immunopathology, v. 66, n. 3-4, p. 331-341, 1998.

DA SILVA VAZ Jr., I. et al. Functional bovine immunoglobulins in Boophilus microplus hemolymph. Veterinary Parasitology, v. 62, n. 1-2, p. 155-160, 1996.

DE ROSE, R. et al. Bm86 antigen induces a protective immune response against Boophilus microplus following DNA and protein vaccination in sheep. Veterinary Immunology and Immunopathology, v. 71, n. 3-4, p. 151-160, 1999. 
DE VOS, S. et al. Evidence for the utility of the Bm86 antigen from Boophilus microplus in vaccination against other tick species. Experimental \& Applied Acarology, v. 25, n. 3, p. 245-261, 2001.

EVANS, D. E.; MARTINS, J. R.; GUGLIELMONE, A. A. A review of the ticks (Acari, ixodida) of Brazil, their hosts and geographic distribution - 1. The state of Rio Grande do Sul, Southern Brazil. Memórias do Instituto Oswaldo Cruz, v. 95, n. 4, p. 453-470, 2000.

FAGOTTO, F. Regulation of Yolk Degradation, Or How to Make Sleepy Lysosomes. Journal of Cell Science, v. 108, p. 3645-3647, 1995.

FERNANDES, E. K. et al. Entomopathogenic potential of Metarhizium anisopliae isolated from engorged females and tested in eggs and larvae of Boophilus microplus (Acari: Ixodidae). Journal of Basic Microbiology, v. 44, n. 4, p. 270-274, 2004.

FIALHO, E. et al. Cathepsin D-mediated yolk protein degradation is blocked by acid phosphatase inhibitors. Archives of Biochemistry and Biophysics, v. 436, n. 2, p. 246-253, 2005.

FOGACA, A. C. et al. Ixodidin, a novel antimicrobial peptide from the hemocytes of the cattle tick Boophilus microplus with inhibitory activity against serine proteinases. Peptides, v. 27, n. 4, p. 667-674, 2005.

FOGACA, A. C. et al. Antimicrobial activity of a bovine hemoglobin fragment in the tick Boophilus microplus. Journal of Biological Chemistry, v. 274, n. 36, p. 25330-25334, 1999.

FOGACA, A. C. et al. Cysteine-rich antimicrobial peptides of the cattle tick Boophilus microplus: isolation, structural characterization and tissue expression profile. Developmental and Comparative Immunology, v. 28, n. 3, p. 191-200, 2004.

FRAGOSO, H. et al. Protection against Boophilus annulatus infestations in cattle vaccinated with the $B$. microplus $B$ m86-containing vaccine Gavac. Vaccine, v. 16, n. 20, p. 1990-1992, 1998.

FRAZZON, A. P. G. et al. In vitro assessment of Metarhizium anisopliae isolates to control the cattle tick Boophilus microplus. Veterinary Parasitology, v. 94, n. 1-2, p. 117-125, 2000.

GARCIA-GARCIA, J. C. et al. Control of ticks resistant to immunization with Bm86 in cattle vaccinated with the recombinant antigen Bm95 isolated from the cattle tick, Boophilus microplus. Vaccine, v. 18, n. 21, p. $2275-2287,2000$.

GASPARIN, G. et al. Mapping of quantitative trait loci controlling tick Riphicephalus (Boophilus) microplus resistance on bovine chromosomes 5, 7 and 14. Animal Genetics, v. 38, n. 5, p. 453-459, 2007.

GIORGI, F.; POSTLETHWAIT, J. H. Yolk Polypeptide Secretion and Vitelline Membrane Deposition in A Female Sterile Drosophila Mutant. Developmental Genetics, v. 6, n. 2, p. 133-150, 1985.

IMAMURA, S. et al. Recent topics of candidate antigens for immunological control of ixodid ticks. Acta Scientiae Veterinariae, v. 35, n. 1, p. 1-16, 2007.

KASHINO, S. S. et al. Boophilus microplus: the pattern of bovine immunoglobulin isotype responses to high and low tick infestations. Experimental Parasitology, v. 110, n. 1, p. 12-21, 2005.

KEMP, D. H. et al. Vaccination against Boophilus microplus: localization of antigens on tick gut cells and their interaction with the host immune system. Experimental \& Applied Acarology, v. 7, n. 1, p. 43-58, 1989.

KLAFKE, G. M. et al. Larval immersion tests with ivermectin in populations of the cattle tick Rhipicephalus (Boophilus) microplus (Acari:
Ixodidae) from State of Sao Paulo, Brazil. Veterinary Parasitology, v. 142, n. 3-4, p. 386-390, 2006.

LARA, F. A. et al. Tracing heme in a living cell: hemoglobin degradation and heme traffic in digest cells of the cattle tick Boophilus microplus. Journal of Experimental Biology, v. 208, n. Pt 16, p. 3093-3101, 2005.

LARA, F. A. et al. A new intracellular pathway of haem detoxification in the midgut of the cattle tick Boophilus microplus: aggregation inside a specialized organelle, the hemosome. Journal of Experimental Biology, v. 206, n. 10, p. 1707-1715, 2003.

LEAL, A. T. et al. Vaccination of bovines with recombinant Boophilus Yolk pro-Cathepsin. Veterinary Immunology and Immunopathology, v. 114, n. 341-355, 2006.

LEEMON, D. M.; JONSSON, N. N. Laboratory studies on Australian isolates of Metarhizium anisopliae as a biopesticide for the cattle tick Boophilus microplus. Journal of Invertebrate Pathology, v. 97, n. 1, p. 40-49, 2008.

LIMA, C. A.; SASAKI, S. D.; TANAKA, A. S. Bmeystatin, a cysteine proteinase inhibitor characterized from the tick Boophilus microplus. Biochemical and Biophysical Research Communications, v. 347, n. 1, p. 44-50, 2006.

LOGULLO, C. et al. Binding and storage of heme by vitellin from the cattle tick, Boophilus microplus. Insect Biochemistry and Molecular Biology, v. 32, n. 12, p. 1805-1811, 2002.

LOGULLO, C. et al. Isolation of an aspartic proteinase precursor from the egg of a hard tick, Boophilus microplus. Parasitology, v. 116, p. 525-532, 1998.

MARTINS, J. R. et al. Partial strategic tick control within a herd of European breed cattle in the state of Rio Grande do Sul, southern Brazil. Experimental \& Applied Acarology, v. 27, n. 3, p. 241-251, 2002.

MARTINS, J. R.; FURLONG, J. Avermectin resistance of the cattle tick Boophilus microplus in Brazil. Veterinary Record, v. 149, n. 2, p. 64, 2001.

MAYA-MONTEIRO, C. M. et al. HeLp, a heme-transporting lipoprotein with an antioxidant role. Insect Biochemistry and Molecular Biology, v. 34 , n. 1, p. $81-87,2004$.

MAYA-MONTEIRO, C. M. et al. HeLp, a heme lipoprotein from the hemolymph of the cattle tick, Boophilus microplus. Journal of Biological Chemistry, v. 275, n. 47, p. 36584-36589, 2000.

MULENGA, A. et al. Blood meal acquisition by ticks; molecular advances and implications for vaccine development. Japanese Journal of Veterinary Research, v. 49, n. 4, p. 261-272, 2002.

MURRELL, A.; BARKER, S. C. Synonymy of Boophilus Curtice, 1891 with Rhipicephalus Koch, 1844 (Acari: Ixodidae). Systematic Parasitology, v. 56, n. 3, p. 169-172, 2003.

NAGARAJ, S. H. et al. A hitchhiker's guide to expressed sequence tag (EST) analysis. Briefings in Bioinformatics, v. 8, n. 1, p. 6-21, 2007.

ODONGO, D. et al. Vaccination of cattle with TickGARD induces cross-reactive antibodies binding to conserved linear peptides of Bm86 homologues in Boophilus decoloratus. Vaccine, v. 25, n. 7, p. 1287-1296, 2007.

OLIVEIRA, P. L.; PETRETSKI, D. D.; MASUDA, H. Vitellin Processing and Degradation During Embryogenesis in Rhodnius-Prolixus. Insect Biochemistry, v. 19, n. 5, p. 489, 1989. 
PATARROYO, J. H. et al. Immunization of cattle with synthetic peptides derived from the Boophilus microplus gut protein (Bm86). Veterinary Immunology and Immunopathology, v. 88, n. 3-4, p. 163-172, 2002.

PECONICK, A. P. et al. Synthetic vaccine (SBm7462) against the cattle tick Rhipicephalus (Boophilus) microplus: Preservation of immunogenic determinants in different strains from South America. Experimental Parasitology, v. 119, n. 1, p. 37-43, 2008.

PENICHET, M. et al. Detection of Bm86 antigen in different strains of Boophilus microplus and effectiveness of immunization with recombinant Bm86. Parasite Immunology, v. 16, n. 9, p. 493-500, 1994.

POHL, P. C. et al. An extraovarian aspartic protease accumulated in tick oocytes with vitellin-degradation activity. Comparative Biochemistry and Physiology Part B: Biochemistry and Molecular Biology, v. 151, n. 4, p. 392-399, 2008.

PRUDENCIO, C. R. et al. In silico analysis for identification of tick phagotopes selected by phage-displayed libraries. Revista Brasileira de Parasitologia Veterinária, v. 18, p. 45-47, 2009.

PRUETT, J. H. Immunological control of arthropod ectoparasites - a review. International Journal for Parasitology, v. 29, n. 1, p. 25-32, 1999.

RAIKHEL, A. S.; DHADIALLA, T. S. Accumulation of Yolk Proteins in Insect Oocytes. Annual Review of Entomology, v. 37, p. 217-251, 1992.

RENARD, G. et al. Expression and immunolocalization of a Boophilus microplus cathepsin L-like enzyme. Insect Molecular Biology, v. 11, n. 4, p. 325-328, 2002.

RIBOLLA, P. E. M.; DAFFRE, S.; DEBIANCHI, A. G. Cathepsin-B and Acid-Phosphatase Activities During Musca-Domestica Embryogenesis. Insect Biochemistry and Molecular Biology, v. 23, n. 2, p. 217-223, 1993.

ROBERTS, J. A. Resistance of cattle to the tick Boophilus microplus (Canestrini). I. Development of ticks on Bos taurus. Journal of Parasitology, v. 54, n. 4, p. 663-666, 1968.

RODRIGUEZ, M. et al. Effect of vaccination with a recombinant Bm86 antigen preparation on natural infestations of Boophilus microplus in grazing dairy and beef pure and cross-bred cattle in Brazil. Vaccine, v. 13 , n. 18 , p. 1804-1808, 1995.
RUIZ, L. M. et al. Immune response in mice and cattle after immunization with a Boophilus microplus DNA vaccine containing bm86 gene. Veterinary Parasitology, v. 144, n. 1-2, p. 138-145, 2007.

SALES-JUNIOR, P. A. et al. Use of biodegradable PLGA microspheres as a slow release delivery system for the Boophilus microplus synthetic vaccine $S B m 7462$. Veterinary Immunology and Immunopathology, v. 107, n. 3-4, p. 281-290, 2005.

SANTOS, I. K. F. de M. et al. Gene discovery in Boophilus microplus, the cattle tick: the transcriptomes of ovaries, salivary glands, and hemocytes. Annals of the New York Academy of Sciences, v. 1026, p. 242-246, 2006.

SASAKI, S. D. et al. Boophilus microplus tick larvae, a rich source of Kunitz type serine proteinase inhibitors. Biochimie, v. 86, n. 9-10, p. 643-649, 2004.

SEIXAS, A. et al. A Boophilus microplus vitellin-degrading cysteine endopeptidase. Parasitology, v. 126, p. 155-163, 2003.

SEIXAS, A. et al. Vaccine potential of a tick vitellin-degrading enzyme (VTDCE). Veterinary Immunology and Immunopathology, v. 124, n. 3-4, p. 332-340, 2008.

SORGINE, M. H. et al. A heme-binding aspartic proteinase from the eggs of the hard tick Boophilus microplus. Journal of Biological Chemistry, v. 275, n. 37, p. 28659-28665, 2000.

SOSSAI, S. et al. Polymorphism of the bm86 gene in South American strains of the cattle tick Boophilus microplus. Experimental \& Applied Acarology, v. 37, n. 3-4, p. 199-214, 2005.

TANAKA, A. S. et al. A double headed serine proteinase inhibitor human plasma kallikrein and elastase inhibitor - from Boophilus microplus larvae. Immunopharmacology, v. 45, n. 1-3, p. 171-177, 1999.

WAGLAND, B. M.; SUTHERST, R. W.; ROBERTS, J. A. Relationship between the resistance of cattle to Haemaphysalis longicornis and to Boophilus microplus. Australian Veterinary Journal, v. 62, n. 9, p. 308-310, 1985.

WILLADSEN, P.; MCKENNA, R. V.; RIDING, G. A. Isolation from the cattle tick, Boophilus microplus, of antigenic material capable of eliciting a protective immunological response in the bovine host. International Journal for Parasitology, v. 18, n. 2, p. 183-189, 1988.

WILLADSEN, P. et al. Immunologic control of a parasitic arthropod. Identification of a protective antigen from Boophilus microplus. Journal of Immunology, v. 143, n. 4, p. 1346-1351, 1989. 